\title{
PROFIL ASAM LEMAK TUNA (Thunnus albacares) LOIN DENGAN PENYEMPROTAN FILTERED SMOKE SELAMA PENYIMPANAN BEKU
}

\author{
Cindy Regina Magdalena Loppies, Daniel A.N. Apituley, \\ Raja Bonan Dolok Sormin ${ }^{\star}$, Beni Setha, Johanis Hiariej \\ Fakultas Perikanan dan Ilmu Kelautan, Universitas Pattimura. \\ Jalan Mr.Chr.Soplanit. Kampus Poka, Ambon. 97123 \\ Diterima: 06 September 2020/Disetujui: 29 Maret 2021 \\ ^Korespondensi: sormindolok@gmail.com
}

Cara sitasi: Loppies CRM, Apituley DAN, Sormin RBD, Setha B, Hiariej J. Profil asam lemak tuna (Thunnus albacares) loin dengan penyemprotan filtered smoke selama penyimpanan beku. Jurnal Pengolahan Hasil Perikanan Indonesia. 24(1): 60-69.

\begin{abstract}
Abstrak
Warna merah merupakan salah satu faktor penentu kualitas ikan tuna loin. Setelah dipotong dan disimpan ikan tuna akan mengalami perubahan warna, sehingga untuk mempertahankan warna merah pada daging ikan tuna digunakan filtered smoke. Filtered smoke juga dapat mengurangi oksidasi lemak dan mempertahankan kualitas asam lemak. Penelitian ini bertujuan untuk mempelajari komposisi asam lemak tuna loin (Thunnus albacares) yang diperlakukan dengan penyemprotan filtered smoke selama penyimpanan. Penelitian menggunakan metode eksperimen, ikan tuna loin disemprot dengan gas filtered smoke kemudian disimpan beku $\left(-25^{\circ} \mathrm{C}\right)$ selama empat minggu. Pengamatan berlangsung pada minggu ke-0 dan minggu ke-4. Variabel mutu yang diuji adalah profil asam lemak, indeks aterogenik (AI), indeks thrombogenik (TI), kualitas lemak $(\mathrm{h} / \mathrm{H})$ dan indeks poliena. Hasil analisis diperoleh asam lemak sebanyak 29 jenis terdiri dari asam lemak jenuh (SFA) 13, asam lemak tak jenuh tunggal (MUFA) 6 dan asam lemak tak jenuh jamak (PUFA) 13. SAFA tertinggi adalah asam palmitat (C16:0), sebesar 8,93\% dan 15,14\%, MUFA tertinggi adalah asam oleat (C18:1n9c) sebesar 3,73\% dan 5,01\% dan PUFA tertinggi adalah asam dokosaheksaenoat (C22:6n3) sebesar 6,77\% dan 5,73\%, masing-masing untuk minggu ke 0 dan minggu ke 4 . Kualitas lemak ikan tuna masih tergolong baik setelah disimpan selama empat minggu, dengan nilai AI 0,83, nilai TI 0,69, nilai h/H 1,72 dan nilai indeks polien 1,31.
\end{abstract}

Kata kunci: filtered smoke, profil asam lemak, tuna loin

\section{Fatty Acid Profiles of Tuna Loin (Thunnus albacares) Sprayed by Filtered Smoke during Frozen Storage}

\begin{abstract}
The red color is one of the factors that determining freshness of tuna loin. To keep the red color of the tuna flesh, it has been treated by filtered smoke. Filtered smoke reduces the oxidative of fat as well as keep the fat quality. The objective of this research was to study the fatty acid composition of tuna (Thunnus albacares) loin treated by filtered smoke. The research method was conducted experimentally. Tuna loin firstly sprayed by filtered smoke at a pressure $1 \mathrm{~atm}$ for 5-10 seconds before storage at freezing temperature $-25{ }^{\circ} \mathrm{C}$ for four weeks. Observations were 0 and 4 weeks and the parameters observed were the fatty acid profiles, atherogenic index (AI), thrombogenic index (TI), fat quality $(\mathrm{h} / \mathrm{H})$ and the index of polien. The result showed there were 29 types of fatty acids consisting of 13 types of saturated fatty acids (SFA), 6 types of monounsaturated fatty acids (MUFA) and 11 types of poly unsaturated fatty acids (PUFA). There were identified as the highest SAFA, MUFA, PUFA for storage time 0 and 4 weeks were palmitic acid $(\mathrm{C} 16: 0)$ 8.93\%; 15.14\%, oleic acid (C18:1n9c) 3.73\%; 5.01\% and docosahexaenoic acid, (C22:6n3) 6.77\% ; 5.73\% respectively. It indicated that the fatty acid of tuna loin were categorized good, where it was indicated by the $\mathrm{AI}, \mathrm{TI}, \mathrm{h} / \mathrm{H}$ and polien index for storage time 0 and 4 weeks $1.11 ; 0.83,0.50 ; 0.69,1.49 ; 1.72$, and $1.49 ; 1.31$ respectively.
\end{abstract}

Keyword: fatty acid profile, filtered smoke, tuna loin 


\section{PENDAHULUAN}

Indonesia merupakan negara penghasil tuna yang memiliki potensi dalam perdagangan tuna internasional. Hasil tangkapan tunatongkol-cakalang (TTC) dengan nilai USD 176,63 juta (14,23\%), cumi-sotong-gurita dengan nilai USD 131,94 juta (10,63\%) (KKP 2020). Kualitas ikan yang diharapkan adalah kualitas sesuai standar mutu ekspor, oleh karena itu perlu penanganan ikan segera setelah ikan ditangkap. Salah satu faktor penentu agar tuna loin yang diekspor diterima oleh konsumen yaitu warna. Warna daging pada makanan laut memiliki pengaruh yang kuat pada penerimaan konsumen. Warna merah cerah merupakan faktor penting penentu kualitas pada makanan laut, terutama ikan tuna. Setelah proses pemotongan membentuk loin dan selama penyimpanan beku, ikan tuna mengalami perubahan warna yang cepat menjadi warna cokelat (Anderson dan $\mathrm{Wu}$ 2005). Salah satu kemunduran mutu ikan tuna yang disebabkan oleh proses oksidasi yaitu terjadinya penambahan kation pada $\mathrm{Fe}^{2+}$ (ferrous) dalam mioglobin menjadi bentuk $\mathrm{Fe}^{3+}$ (ferric) yang dapat mengakibatkan perubahan warna daging ikan tuna dari merah segar menjadi cokelat (Faustman dan Cassens 1990).

Penggunaan karbon monoksida (CO) maupun filtered smoke (FS) telah diterapkan pada makanan laut dalam upaya untuk mempertahankan warna yang diinginkan selama penyimpanan dan transportasi (Pivarnik et al. 2011). Penggunaan CO dan FS pada penelitian telah dilakukan Ludlow et al. (2004) dan Kristinsson et al. (2008) untuk melihat stabilitas warna dan stabilitas bakteri pada ikan tuna. Gas yang tidak difiltrasi masih mengandung komponen yang dapat memengaruhi bau dan rasa. Karena gas yang difiltrasi tidak berbau dan berasa yang akan memengaruhi produk tuna loin. Gas $\mathrm{CO}$ dan filltered smoke merupa gas yang sudah digunakan secara komersial dalam penanganan tuna loin untuk mempertahankan warna juga mengurangi bakteri dan mengurangi oksidasi lemak, jadi yang mau dilihat bagaimana kualitas asam lemaknya.

Menurut Ludlow et al. (2004) dan Kristinsson et al. (2008) FS dapat mengurangi jumlah bakteri, meningkatkan stabilitas oksidatif dan stabilitas warna merah daging ikan tuna selama penyimpanan. Selanjutnya penggunaan FS dapat mengurangi oksidasi lemak pada asam lemak dan pada akhirnya dapat menunda terjadinya penyimpangan rasa dan bau pada daging ikan (Faustman et al. 1989).

FS adalah produk asap hambar yang diproduksi dengan pembakaran kayu dengan suhu $850^{\circ} \mathrm{F}$ atau $454{ }^{\circ} \mathrm{C}$ selanjutnya proses filtrasi dan pemurnian untuk menghilangkan partikulat yang ditemukan pada asap. Komponen utama dalam FS adalah nitrogen $\left(\mathrm{N}_{2}\right)$, oksigen $\left(\mathrm{O}_{2}\right)$, karbonmonoksida $(\mathrm{CO})$, karbondioksida $\left(\mathrm{CO}_{2}\right)$, metana $\left(\mathrm{CH}_{4}\right)$, fenol aromatik dan hidrokarbon (Hahn 1999).

Pada penanganan tuna selain memperhatikan warna, perlu juga diketahui dampak penggunaan FS terhadap kualitas asam lemak daging ikan tuna, karena kandungan asam lemak hewan laut khususnya yang tidak jenuh jamak umumnya berperan penting pada kesehatan.

Pada tubuh asam lemak mempunyai kegunaan yang penting, yaitu untuk mempertahankan kekuatan membran sel, memproduksi hormon ekosanoik yang berfungsi dalam pengaturan tekanan darah, pembekuan darah, juga berperan dalam pengaturan lemak darah serta respons imun luka dan infeksi (Thoha 2004). Penelitian ini bertujuan untuk mempelajari komposisi asam lemak ikan tuna loin yang menggunakan filter smoke (FS) selama penyimpanan beku.

\section{BAHAN DAN METODE Bahan dan Alat}

Penelitian menggunakan ikan tuna loin, filtered smoke (digunakan secara komersial oleh perusahan Harta Samudra yang berasal dari kayu terbaik yang dibuat di Hawaii), karbon monoksida (30\% sampai 40\% CO dalam nitrogen) yang didapat dari PT Harta Samudra. Zat kimia yang dibutuhkan antara lain : $\mathrm{NaOH}$ 0,5 N, Metanol p.a (Merck), larutan $\mathrm{BF}_{3} 20 \%$ p.a (Merck), larutan $\mathrm{NaCl}$ jenuh p.a (Merck), heksana teknis (Merck), dan $\mathrm{Na}_{2} \mathrm{SO}_{4}$ anhidrat p.a (Merck). Peralatan yang digunakan adalah kromatografi gas, syringe $10 \mu \mathrm{L}$, penangas air (BTI-57 Biotechnic, 
India), tabung bertutup Teflon, neraca analitik (Ohaus) dan pipet mikro.

\section{Metode Penelitian \\ Persiapan sampel}

Sampel ikan tuna loin di potong berbentuk saku dan dimasukkan dalam plastik kemudian di semprot dengan filter smoke (FS) pada tekanan 1 atm selama 10 detik, selanjutnya plastik ditutup dan diikat. Kemudian disimpan dalam suhu pendinginan $4{ }^{\circ} \mathrm{C}$ selama 2 hari. Setelah 2 hari gas filter smoke di dikeluarkan dari dalam plastik dan daging ikan dikemas vakum untuk disimpan pada suhu beku pada $-25^{\circ} \mathrm{C}$ selama 4 minggu. Pengamatan dilakukan pada minggu ke-0 dan ke-4.

\section{Analisis asam lemak}

Alat uji asam lemak adalah kromatografi gas (GC) mengikuti prosedur Laboratorium Terpadu IPB Bogor, dengan kandungan asam lemak ditentukan sebagai asam lemak metal ester (FAME). Pembuatan FAME dalam contoh diawali terjadinya proses hidrolisis dan esterifikasi. Sejumlah 20-30 sampel ditempatkan pada tabung reaksi dengan tutup liner teflon yang telah ditambahkan $1 \mathrm{~mL} \mathrm{NaOH}(0,5 \mathrm{~N})$ pemanasan dilakukan dalam wadah sekitar 20 menit. Langkah selanjutnya adalah penambahan larutan $\mathrm{BF}_{3}$ $16 \%$ sebanyak $2 \mathrm{~mL}$ dan standar internal sebanyak $5 \mathrm{mg} / \mathrm{mL}$ dan pemanasan 20 menit. Dilakukan penambahan larutan $\mathrm{NaCl}$ jenuh sebanyak $2 \mathrm{~mL}$ dan larutan heksan $1 \mathrm{~mL}$ setelah contoh didinginkan. Ke dalam tabung berisi sebanyak $0,1 \quad \mathrm{~g} \mathrm{Na}_{2} \mathrm{SO}_{4}$ anhidrida dimasukkan lapisan heksan menggunakan pipet dan diinkubasi selama sekitar 15 menit. Kemudian $5 \mu \mathrm{L}$ sampel yang dicampur dengan fase cair standar FAME menggunakan siring dimasukkan ke dalam kolom kromatografi gas (minyak metil sianopropil, Sigma-Aldrich, AS; $100 \mathrm{mx} 0,25 \mathrm{~mm}$ ID, $0,20 \mathrm{um}$ ). Setelah itu, $5 \mu \mathrm{L}$ sampel diinjeksikan. Kondisi operasional kromatografi gas adalah: temperatur injektor $200{ }^{\circ} \mathrm{C}$, suhu detektor kapiler (detektor FID 2010 plus) $230{ }^{\circ} \mathrm{C}$, suhu kolom dikondisikan pada suhu $190{ }^{\circ} \mathrm{C}$ selama 15 menit di awal dan suhu $230{ }^{\circ} \mathrm{C}$ selama 20 menit di akhir, pembawa $\mathrm{H}_{2}$ gas, laju aliran gas $\mathrm{H}_{2} 30 \mathrm{~mL} /$ menit, gas $\mathrm{N}_{2} 20 \mathrm{~mL} /$ menit, dan laju aliran udara 200-250 mL / menit. Kemudian hasilnya dibandingkan dengan standar.

$C x=\frac{\text { Ax.R.Cs }}{\text { As }}$

Keterangan:

$\mathrm{Cx}=$ komposisi bahan;

$\mathrm{Cs}=$ komposisi internal standar;

$\mathrm{Ax}=$ permukaan bahan;

As=luas standar internal;

$\mathrm{R}=$ respons terhadap standar dari komponen

detector relative

Untuk metode standar eksternal, preparasi sama tetapi standar tidak ditambahkan ke dalam sampel. Konsentrasi komponen dapat dihitung dengan rumus

Konsentrasi $=\frac{\frac{\mathrm{Ax}}{\mathrm{As}} \times \mathrm{C} \text { standar x V } \frac{\text { sampel }}{100} \times 100 \%}{\text { gram (sampel) }}$

\section{Analisis kualitas nutrisi lemak}

Kualitas lemak dinilai melalui indeks atherogenic (IA) dan indeks thrombogenic (IT) yang diadopsi dari Ghaeni et al. (2013).

$\mathrm{IA}=[(4 \mathrm{xC} 14: 0)+\mathrm{C} 16: 0+\mathrm{C} 18: 0] /\left[\right.$ LMUFA $+\sum$ PUFAn6+ + PUFAn3 $]$

$\mathrm{IT}=\frac{(\mathrm{C} 14: 0)+(\mathrm{C} 16: 0)+(\mathrm{C} 18: 0)}{0.5 \text { MUFA }+0.5 \text { PUFAn6+3PUFAn3/PUFAn6 }}$

Rasio hipokolesterolemia dan hiperkolesterolemia (Santos-Silva et al. 2002) diukur melalui persamaan:

$\mathrm{h} / \mathrm{H}=\frac{(\mathrm{C} 18: 1)+(\mathrm{C} 18: 2)+(\mathrm{C} 20: 3)+(\mathrm{C} 20: 4)+(\mathrm{C} 20: 5)+(\mathrm{C} 22: 4)+(\mathrm{C} 22: 6)}{(\mathrm{C} 14: 0)+(\mathrm{C} 16: 0)}$

\section{Analisis Data}

Data hasil penelitian dianalisis secara deskriptif, hasil analisis disajikan dalam bentuk tabel dan grafik.

\section{HASIL DAN PEMBAHASAN Kadar Garam}

Definisi asam lemak adalah untaian rantai asam organik dengan jumlah atom karbon berkisar antara 4 sampai dengan 24, mempunyai gugus karboksil tunggal dan ujungnya berupa nonpolar yang panjang dari hidrokarbon (Apituley 2008). Analisis asam lemak dilakukan untuk mengetahui jenis dan kadar asam lemak yang terdapat dalam tuna loin yang diberi gas filter smoke. Asam lemak pada $i$ kan tuna loin disajikan dalam Table 1. 
Table 1 Fatty Acids Profile of Tuna Loin Sprayed by Filtered Smoke due to Storage Period 0 and 4 Weeks.

\begin{tabular}{|c|c|c|}
\hline Fatty Acid & 0 Week & 4 Week \\
\hline Caprilic acid, C8:0 & - & $0.05 \pm 0.03$ \\
\hline Capric acid, C10:0 & - & $0.04 \pm 0.03$ \\
\hline Lauric Acid, C12:0 & $0.11 \pm 0.02$ & $0.28 \pm 0.05$ \\
\hline Myristic Acid, C14:0 & $3.80 \pm 0.03$ & $0.96 \pm 0.03$ \\
\hline Palmitic Acid, C16:0 & $8.93 \pm 0.02$ & $17.42 \pm 0.03$ \\
\hline Pentadecanoic Acid, C15:0 & $0.19 \pm 0.04$ & $0.17 \pm 0.01$ \\
\hline Heptadecanoic Acid, C17:0 & $0.47 \pm 0.02$ & $0.35 \pm 0.03$ \\
\hline Stearic Acid, C18:0 & $5.86 \pm 0.03$ & $5.96 \pm 0.02$ \\
\hline Arachidic Acid, C20:0 & $0.21 \pm 0.04$ & $0.22 \pm 0.02$ \\
\hline Heneicosanoic Acid, C21:0 & $0.05 \pm 0.06$ & $0.05 \pm 0.03$ \\
\hline Behenic Acid, C22:0 & $0.45 \pm 0.05$ & $0.27 \pm 0.02$ \\
\hline Tricosanoic Acid, C23:0 & $0.11 \pm 0.04$ & $0.05 \pm 0.01$ \\
\hline Lignoceric Acid, C24:0 & $0.26 \pm 0.05$ & $0.20 \pm 0.01$ \\
\hline Palmitoleic Acid, C16:1 & $0.54 \pm 0.05$ & $0.74 \pm 0.02$ \\
\hline Cis-10-Heptadecanoic Acid, C17:1 & $0.12 \pm 0.03$ & $0.05 \pm 0.01$ \\
\hline Elaidic Acid, C18:1n9t & $0.06 \pm 0.01$ & $0.42 \pm 0.04$ \\
\hline Oleic Acid, C18:1n9c & $3.73 \pm 0.04$ & $13.46 \pm 0.03$ \\
\hline Cis-11-Eicosenoic Acid, C20:1 & $0.11 \pm 0.03$ & $0.34 \pm 0.03$ \\
\hline Nervonic Acid, C24:1 & $0.62 \pm 0.08$ & $0.53 \pm 0.05$ \\
\hline Linolelaidic Acid, C18:2n9t & - & $0.63 \pm 0.03$ \\
\hline Linoleic Acid, C18:2n6c & $0.53 \pm 0.04$ & $7.35 \pm 0.03$ \\
\hline g-Linolenic Acid, C18:3n6 & $0.07 \pm 0.03$ & $0.63 \pm 0.02$ \\
\hline Linolenic Acid, C18:3n3 & $0.05 \pm 0.02$ & $0.56 \pm 0.01$ \\
\hline Cis-11,14-Eicosedienoic Acid, C20:2 & $0.06 \pm 0.02$ & $0.18 \pm 0.03$ \\
\hline Cis-8,11,14-Eicosetrienoic Acid, C20:3n6 & - & $0.17 \pm 0.04$ \\
\hline Arachidonic Acid, C20:4n6 & $1.34 \pm 0.03$ & $1.67 \pm 0.03$ \\
\hline Cis-13,16-Docosadienoic Acid, C22:2 & $0.07 \pm 0.05$ & - \\
\hline Cis-5,8,11,14,17-Eicosapentaenoic Acid, C20:5n3 & $0.73 \pm 0.02$ & $0.98 \pm 0.01$ \\
\hline Cis-4,7,10,13,16,19-Docosahexaenoic Acid, C22:6n3 & $6.77 \pm 0.02$ & $5.73 \pm 0.03$ \\
\hline Total & 32.45 & 59.46 \\
\hline$\sum$ Saturated Fatty Acid (SFA) & 17.02 & 26.02 \\
\hline$\sum$ Monounsaturated Fatty Acid (MUFA) & 5.18 & 15.54 \\
\hline$\Sigma$ Polyunsaturated Fatty Acid (PUFA) & 10.25 & 17.90 \\
\hline PUFA/SAFA & 0.60 & 0.69 \\
\hline n-3 PUFA & 7.55 & 7.27 \\
\hline n-6 PUFA & 1.94 & 9.82 \\
\hline$n-3 / n-6$ & 3.90 & 0.74 \\
\hline IA & 1.11 & 0.83 \\
\hline IT & 0.50 & 0.69 \\
\hline $\mathrm{h} / \mathrm{H}$ & 1.49 & 1.72 \\
\hline PI & 1.49 & 1.31 \\
\hline
\end{tabular}


Hasil analisis asam lemak (Table 1) menunjukkan telah teridentifikasi asam lemak sebanyak 29 jenis dengan perincian: asam lemak jenuh 13 jenis, asam lemak tidak jenuh tunggal 6 jenis dan asam lemak tidak jenuh jamak 10 jenis. Total asam lemak jenuh (SFA) dengan perlakuan penyemprotan filtered smoke minggu ke-0 dan ke-4 masing-masing adalah $17,02 \%$ dan $26,02 \%$, asam lemak jenuh tunggal (MUFA) 5,18\% dan 15,54\% dan asam lemak tak jenuh jamak (PUFA) 9,62\% dan 17,90\%. Berge dan Barnatha (2005) mengemukakan bahwa kandungan asam lemak jenuh (SAFA) dalam ikan berkisar 15-25\%, asam lemak tidak jenuh tunggal (MUFA) berkisar 35-60\%, sedangkan asam lemak tidak jenuh jamak (PUFA) 25-40\%. Terjadinya perubahan kandungan asam lemak tidak selalu disebabkan oleh oksidasi atau hidrolisis terjadinya kenaikan atau penurunan terjadi secara relatif apabila satu komponen naik maka komponen yang lain turun.

Figure 1 menunjukkan bahwa asam lemak jenuh (SFA) didominasi oleh asam palmitat (C16:0) dan dan asam stearat (C18:0). Pemberikan gas filtered smoke pada tuna loin, menunjukkan bahwa minggu ke-0 dan minggu ke-4 kandungan asam palmitat berturut-turut adalah 8,93 dan 17,42\%, sedangkan asam stearat masing-masing 5,86 dan 5,96\%. Perbedaan asam lemak (SFA) pada penyimpanan diakibatkan adanya oksidasi lemak yang terjadi pada penyimpanan suhu dingin sehingga aktivitas enzim dan gerakan sel terhambat (Handayani et al. 2014 dalam Jacoeb et al. 2020). Umumnya asam lemak yang paling banyak terkandung dalam makanan adalah asam palmitat dari jenis asam lemak jenuh, dengan kadar sebesar 15-50\% (Winarno 1997). Asam palmitat dan stearat merupakan jenis asam lemak SFA konsentrasi tertinggi dibandingkan dengan asam lemak lainnya juga dilaporkan dalam beberapa spesies ikan laut (Sahena et al. 2010; Elsdon 2010). Ozugul dan Ozugul (2007) juga menyatakan bahwa komponen utama dari asam lemak jenuh adalah asam palmitat dengan kadar mencapai $53-63 \%$ dari keseluruhan jumlah asam lemak jenuh.

Hasil penelitian (Figure 2) menunjukkan asam lemak dengan jumlah tertinggi yakni
$3,73 \%$ dan $13,46 \%$ berturut-turut pada minggu ke-0 dan ke- 4 adalah asam oleat. Asam ini adalah asam lemak tidak jenuh tunggal terbanyak di alam. Jenis asam lemak tak jenuh tunggal pada ikan didominasi oleh asam oleat dan palmitoleat. Asam oleat merupakan asam lemak esensial. Asam oleat di dalam tubuh berfungsi sebagai sumber energi dan zat antioksidan (Al-Saghir et al. 2004). Ozugul dan Ozugul (2007) menyatakan ikan mengandung asan oleat sebanyak $52-79 \%$ dari keseluruhan asam lemak tidak jenuh tunggal. Asam oleat adalah perintis terbentuknya sebagian besar PUFA. Muchtadi et al. (1993) menyatakan asam oleat termasuk ke dalam kelompok MUFA yang bersifat melindungi, menurunkan jumlah LDL kolesterol darah, dan meningkatkan HDL kolesterol.

Figure 3 menunjukkan asam lemak tidak jenuh jamak (PUFA) didominasi oleh asam dokosaheksaenoat (DHA), asam eikosapentanoat (EPA) dan asam linolelaidat. Hasil penelitian menunjukkan bahwa asam DHA merupakan asam lemak yang tertinggi untuk tuna loin yang disemprot dengan filter smoke dengan jumlah pada minggu ke-0 dan ke-4 sebesar 6,77\% dan 5,73\%. DHA merupakan asam lemak esensial yang berperan dalam mendukung kegiatan fisiologis tubuh dan merupakan bahan yang dibutuhkan oleh sel tertentu seperti sel otak dan sel retina (Akoh dan Min 2008).

Asam lemak kedua tertinggi adalah EPA, yaitu pada penyimpanan minggu ke-0 dan ke-4 masing-masing $0,73 \%$ dan $0,98 \%$. DHA dan EPA merupakan asam lemak tak jenuh jamak yang paling banyak ditemukan pada tuna loin. Perbedaan antara lemak hewan laut dan lemak hewan darat adalah pada hewan laut terdapat asam lemak ratai panjang PUFA seperti EPA dan DHA (Shahidi 2009). Asam-asam lemak ini (EPA dan DHA) adalah bahan utama penyusun fosfolipid membran sel yang bermanfaat dalam menopang sistem saraf pusat (Wu et al. 2010). Sunarya (1993) menyatakan penyusun utama lemak ikan adalah PUFA seperti asam linoleat, linolenat, EPA dan DHA.

Table 1 menunjukkan komposisi asam lemak tuna loin yang diberi filter smoke, terlihat bahwa asam lemak jenuh didominasi 


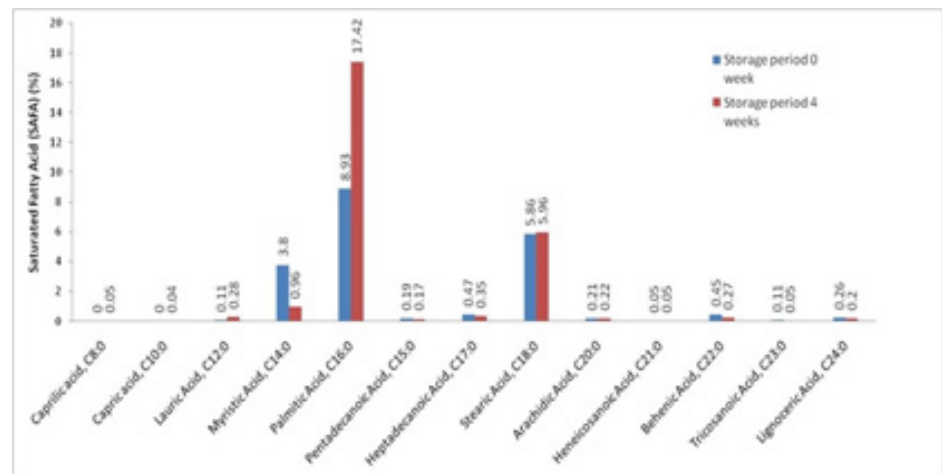

Figure 1 Saturated fatty acid of tuna loin at 0 and 4 weeks storage

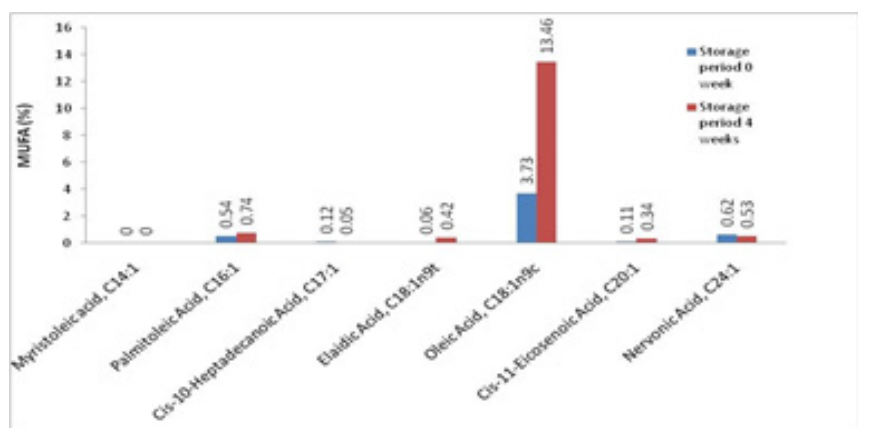

Figure 2 Monounsaturated fatty acids of tuna loin at 0 and 4 weeks storage

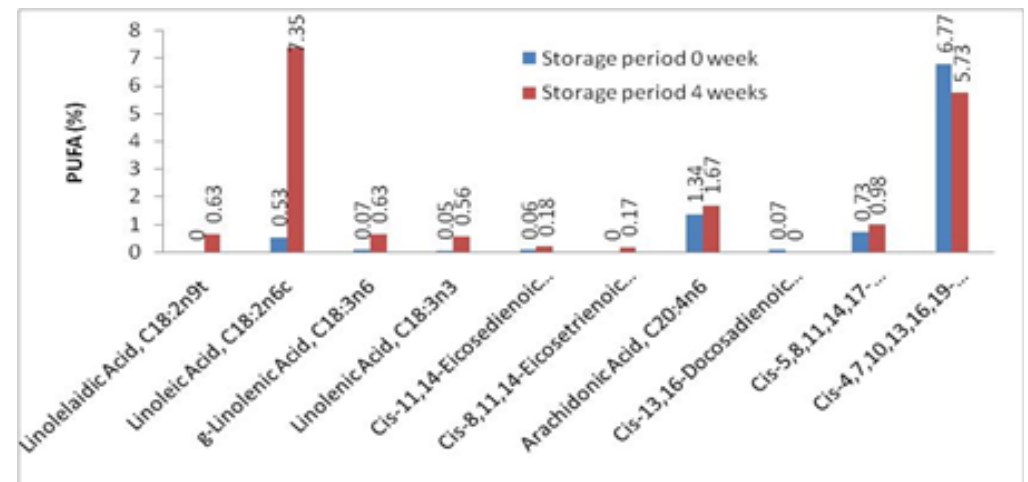

Figure 3 Polyunsaturated fatty acids of tuna loin at 0 and 4 weeks storage

asam palmitat (C16:0), asam lemak jenuh asam oleat $(\mathrm{C} 18: 1 \mathrm{n} 9 \mathrm{c})$, dan asam lemak tak jenuh jamak asam eikosapentanoat, C20:5n3 (EPA) dan asam dokosaheksaenoat, C22:6n3 (DHA). Sunarya (1993) dalam Apituley et al. (2019) menyatakan lemak ikan dan minyak ikan bermanfaat untuk kesehatan karena kandungan asam lemak jenuh jamak (PUFA) misalnya asam oleat, EPA, dan DHA. Asam lemak ini juga berperan dalam mencegah dan mengobati penyakit jantung, hipertensi, arthiritis, peradangan, gangguan kekebalan dan kanker (Jones 2002). Berdasarkan komposisi asam lemak di atas, keberadaan asam linolenat, EPA dan DHA menunjukkan kualitas nutrisi tuna loin termasuk tinggi.

Pada penelitian ini terlihat bahwa PUFA n-3 pada ikan tuna loin segar dan tuna loin pemberian FS selama penyimpanan 4 minggu didominasi oleh DHA dan EPA yang berada pada kisaran $7,55-7,27 \%$ dan tertinggi pada n-3 PUFA minggu ke-0 asam lemak ini yang sedang dipelajari karena memiliki potensi untuk pencegahan dan pengobatan penyakit kardiovaskular seperti hipotrigliseridemia (KrisEtherton et al. 2002; Wozniack et al. 2013).

Profil dari PUFA n-3 dan FUFA n-6 dengan rasio berada pada kisaran 0,74\% 
sampai 3.89 (Figure 4). Nilai ini hampir sama dengan hasil penelitian Mohanti et al. (2016) yang melaporkan bahwa rasio PUFA-n3/ PUFA-n6 di 39 spesies ikan termasuk Thunnus albacares, Rastrelliger kanagurta, Katsuwonus pelamis, dan Euthynnus affinis ditemukan sekitar 0,80-5,6. Dengan cara yang sama, Oklan (2005) menyatakan bahwa rasio PUFA-n3/PUFA-n6 yang tinggi akan memberikan manfaat bagi makanan. Diet terbaik rasio PUFA-n3/PUFA-n6 untuk manusia adalah sekitar 1: 1 sampai 1: 5 seperti dinyatakan oleh Osman dalam Zuraini et al. (2006). Rasio PUFA/SFA yang tinggi dari tuna loin pemberian filter smoke selama penyimpanan dalam penelitian ini yaitu sekitar 0.6 hingga $0.69 \%$ (Figure 4) dan dapat disarankan sebagai sumber PUFA seperti yang direkomendasikan oleh departemen kesehatan Inggris. Rasio minimum PUFA/SFA adalah sekitar 0,45 (Calman dalam Cieslick et al. 2017). Rasio PUFA/SFA yang ditemukan dalam penelitian ini mirip dengan rasio PUFA/ SFA dari rasio tuna sirip kuning dan tuna sirip biru yaitu sekitar 0,64 hingga 0,82 (Peng et al. 2013). Rasio ini didukung oleh indeks atherogenik (IA), indeks trombogenik (TI), hipokolesterolemia dan hiperkolesterolemia $(\mathrm{h} / \mathrm{H})$ serta rasio indeks polien (PI) tuna loin yang diberi filter smoke.

Nilai IA dan IT tuna loin selama penyimpanan 0 dan 4 minggu masing-masing 1,11 dan 0,83 untuk IA serta 0,5 dan 0,65 untuk IT . Nilai-nilai ini mirip dengan nilainilai IA dan IT dari ikan mas, rainbow, dan northern pike yaitu 0,26-0,27 untuk IA dan 0,25-1,06 untuk IT (Chieslic et al. 2017). Namun, Torrial et al. (2014) menemukan bahwa nilai IA dan IT ikan nila sekitar 0,55-0,66 (AI) dan 0,82-0,85 (IT). Menurut Bosciano et al. (2014), makanan berkualitas baik memiliki IA dan IT yang rendah karena dapat digunakan dalam penentuan kualitas lemak makanan termasuk produk perikanan yang lainnya (Ghaeni et al. 2013).

IA terkait dengan interaksi konten lemak jenuh sebagai zat pro-aterogenik dan kandungan lemak tidak jenuh sebagai zat anti-aterogenik. Zat-zat pro-aterogenik menginduksi adhesi lipid dalam sistem kekebalan tubuh, sementara zat-zat anti- aterogenik mencegah pembentukan plak dalam aliran darah karena meminimalkan esterifikasi lemak dalam penyakit jantung koroner. Sementara itu, IT terkait dengan interaksi asam lemak jenuh (protrombogenik) dan asam lemak tak jenuh (antitrombogenik) dalam proses pembekuan darah (Ghaeni et al. 2013; Boscaino et al. 2014). Oleh karena itu, kualitas tuna loin yang diberi filter smoke dalam penelitian ini dianggap baik karena memiliki IA dan IT yang lebih rendah.

Rasio $\mathrm{h} / \mathrm{H}$ tuna loin segar dan tuna loin yang diberi gas filter smoke adalah sekitar 1.49-1.72 (Figure 5). Tonial et al. (2014) melaporkan bahwa rasio h/H ikan nila sekitar 1,56-1,63. Selain itu, rasio $\mathrm{h} / \mathrm{H}$ dari beberapa makanan laut beku seperti udang, cumi-cumi, kerang, dan gurita berturut-turut adalah sekitar 2,54; 2,13; 1,1; dan 2,57 (Czech et al. 2015). Rasio h/H terkait erat dengan kualitas lemak makanan (Santos-Silve et al. 2002). Kandungan asam lemak hipokolesterolemik yang lebih tinggi dalam makanan berarti dapat mencegah aterosklerosis. Hasil penelitian ini terlihat bahwa hingga akhir penyimpanan empat minggu tuna loin dengan pemberian gas filter smoke memiliki nilai $\mathrm{h} / \mathrm{H}$ cukup tinggi yakni 1,72.

Indeks polien (PI) adalah indikator oksidasi lipid (Telahigue et al. 2013), yang ditentukan dari tingkat EPA dan DHA dibandingkan dengan nilai asam palmitat. PI adalah indikator oksidasi lipid (Telahigue et al. 2013), yang ditentukan dari nilai EPA dan DHA dibandingkan dengan nilai asam palmitat. Indeks polien tuna loin menggunakan filter smoke adalah 1.31-1,49 (Figure 5). PI penelitian ini dianggap lebih baik dari hasil penelitian sebelumnya pada makarel (Scomberomorus commerson) dengan IP 0,64 dan hiu (Carcharhinus dussumieri) dengan IP 0,45 (Taheri et al. 2012). Oleh karena itu, dapat dikatakan bahwa tuna loin yang diberi filter smoke sangat tahan terhadap proses oksidasi. Semakin tinggi PI menunjukkan semakin tinggi resistensi sumber makanan terhadap proses oksidasi (Nazemroaya 2009; Pirestani et al. 2010) 


\section{KESIMPULAN}

Perlakuan penyemprotan filtered smoke terhadap tuna loin menghasilkan asam lemak sebanyak 29 jenis terdiri dari asam lemak jenuh 13 jenis, asam lemak tidak jenuh tunggal 6 jenis dan asam lemak tidak jenuh jamak 10 jenis. Selama penyimpanan dengan menggunakan FS, terlihat asam lemak masih dalam keadaan baik dengan ditunjukan oleh IP (indeks polien).

Asam palmitat beserta asam stearat mendominasi asam lemak jenuh, sementara asam oleat, asam dokosaheksanoat (DHA), asam eikosapentaenoat (EPA) dan asam linolelaidat mendominasi asam lemak tidak jenuh. Berdasarkan indeks IA, IT, h/H dan polien indeks sampai akhir penyimpanan memperlihatkan kualitas lemak tuna loin tergolong baik.

\section{DAFTAR PUSTAKA}

Anderson CR, Wu WH. 2005. Analysis of carbon monoxide in commercially treated tuna (Thunnus spp.) and mahimahi (Coryphaena hippurus) by gas chromatography/mass spectrometry. Journal of Agricultural and Food Chemistry. 53: 7019-23.

Akoh CC, Min DB. 2008. Food Lipid Chemistry Nutrition and Biotechnology. 3rd ed. US: CRS Press.

Al-Saghir S, Thurner K, Wagner KH, Frisch G, Luf W. 2004. Effects of different cooking procedures on lipid quality and cholesterol oxidation of farmed salmon fish (Salmo salar). Journal of Agricultural and Food Chemistry. 52: 5290-5296.

Apituley DAN. 2008. Kimia Pangan. Ambon (ID): Program Studi Teknologi Hasil Perikanan. Fakultas Perikanan dan Ilmu Kelautan. Universitas Pattimura.

Apituley DAN, Loppies CRM. 2017. Aplikasi Teknologi Asap Cair Sebagai Upaya Perbaikan Pengolahan Ikan Asar secara Tradisional di Propinsi Maluku. Ambon (ID): Penerbit Program Studi Teknologi Hasil Perikanan FPIK UNPATTI Ambon. Apituley DAN, Loppies CRM, Setha B. 2019. Amino Acid dan Fatty Acid Profiles of Tuna and smoked Tuna . International Journal of Recent Scientific Research.

\section{IJRSFP (USA)}

Bergé JP, Barnathan G. 2005. Fatty acids from lipids of marine organisms: molecular biodiversity, roles as biomarkers, biologically active compounds, and economical aspects. Advances in Biochemical Engineering/Biotechnology. 96: 49-125.

Boscaino F, Ascierno V, Saggese P, Cozzolino R, Motta CM, Sorrentino A. 2014. Effectivenes of vacuum devices for home storage of rainbow trouts from game fishing lakes. African Journal of Science and Research. 3(2):18-24.

Cieslick I, Migdal W, Topolska K, Mickowska B, Cieslick E. 2017. Change of amino acid and fatty acid profile in freshwater fish after smoking.Journal of Food Processing and Preservation. 2017:e1357.

Czech A, Grela ER, Ognik K. 2015. Effect of frying on nutrients content on fatty acids composition of muscles of selected freezing seafoods. Journal of Food and Nutrition Research. 3(1):9-14.

Elsdon TS. 2010. Unraveling diet and feeding histories of fish using fatty acids as natural tracers. Journal of Experimental Marine Biology and Ecology. 386: 61-68.

Faustman C, Cassens RG, Schaefer DM, Buege DR, Williams SN, Sheller KK. 1989. Improvement of pigment and lipid stability in Holstein steer beef by dietary supplementation of vitamin E. Journal of Food Science. 54(4): 858-862.

Ghaeni M, Ghahfaroki KN, Zaheri L. 2013. Fatty acids profile, atherogenic (IA) and thrombogenic (IT) health lipid indices in Leiognathus bindus and Upeneus sulphureus. Journal of Marine Science: Research \& Development. 3(4):1-3.

Hahn MJ. 1999. Use of Tasteless Smoke. Washington (US): Hawaii International Seafood, Inc.

Jacoeb AM, Hidayat T, Nurjanah N. 2020. Komposisi kimia dan profil asam, lemak ikan layur segar penyimpanan suhu dingin. Jurnal Pengolahan Hasil Perikanan Indonesia. 23(1): 147-157.

Jones JHP. 2002. Effect of n-3 Poly unsaturated fatty acids on risk reduction of sudden death. Nutrition Reviews. 60(12):407-413. 
[KKP]. Kementerian Kelautan dan Perikanan. 2020. Laporan Triwulan I 2020. Nilai Ekspor Perikanan Capai USD1,24 Miliar Jakarta(ID): Humas Dtjen PDSPKP, Kementerian Kelautan dan Perikanan.

Kristinsson HG, Mony S, Demir N, Balaban MO, Otwell WS. 2008. The effect of carbon monoxide and filtered smoke on the properties of aquatic muscle and selected muscle com ponents. Taft 2003. Proceedings of the TAFT 2003 Conference. Reykjavik. Iceland: pp. 2729.

Kris-Etherton PM, Haris WS, Appel L.J. 2002. Fish consumption, fish oil, omega 3 fatty acids and cardiovascular disease. Circulation.106: 2747-2757.

Ludlow N, Kristinsson HG, Balaban MO, Otwell WS, Welt B. 2004. Effect of different carbonmonoxide and filtered smoke treatments on the quality and safety of yellowfin tuna (Thunnus albacares) muscle. IFT annual meeting, July 12-16, 2004, Las Vegas, Nev. Abstract 49B-26.Chicago, Ill.: Institute of Food Technologists.

Mohanty B, Mahanty A, Ganguly S, Sankar TV, Chakraborty, Rangasamy A, Sharmal AP. 2014. Amino acid compositions 27 food fishes and their importance in clinical nutrition. Journal Amino Acids. 2014. 7-14.

Muchtadi D, Astawan M, Palupi NS. 1993. Metabolisme Zat Gizi Sumber, Fungsi dan Kebutuhan bagi Manusia. Jakarta (ID): Pustaka Sinar Harapan.

Nazemroaya S, Sahari AM, Rezaei M. 2009. Effect of frozen storage on fatty acid composition and changes in lipid content of Scomberomorus commerson and Carcharhinus dussumieri. Journal Application Ichthyology. 25: 91-95.

Okland HMW, Stoknes LS, Remme JF, Kjerstad M, Synnes M. 2005. Proximate composition, fatty acids anf lipid class composition of the muscle from deep-sea teleost and elasmobranchs. Comparative Biochemistry and Physiology. Part B 140:437-443

Ozugul Y, Ozugul F. 2007. Fatty acid profiles of comercially important fish species from the mediterranean, agean and black seas. Food Chemistry. 100(4):1634-1638

Pirestani S, Sahari MA, Barzegar M. 2010. Fatty acids changes during frozen storage in several fish species from south caspian sea. Journal of Agricultural Science and Technology.12: 321-329

Pivarnik, Lori F, Faustman C, Rossi S, Suman SP, Palmer C, Richard NL, Ellis PC, DiLiberti M. (2011). Quality Assessment of Filtered Smoked Yellowfin Tuna (Thunnus albacares) Steaks. Publications, Agencies and Staff of the U.S. Department of Commerce. Paper 307.

Rodríguez A, Losada V, Larraín MA, Quitral V, Vinagre J, Aubourg SP. 2007. Development of lipid changes related to quality loss during the frozen storage of farmed coho salmon (Oncorhynchus kisutch).Journal of the American Oil Chemists' Society. 84: 727-734

Sahena F, Zaidul ISM, Jinap S, Jahurul MHA, Khatib A, Norulaini NAN. 2010. Extraction of fish oil from the skin of Indian mackerel using supercritical fluids. Journal of Food Engineering. 99:63-69.

Santos-Silva J, Bessa RJB, Santos-Silva F. 2002. Effects of Genotype, feeding system and slaughter weight ion the quality of light lambs: Fatty acid composition of meat. Live Stock Production Science. 77: 187194.

Shahidi F. 1998. Flavor of Meat, Meat Product and Seafoods. Second Edition. CA: Blackie academic and Profesional.

Shahidi F. 2009. Omega-3 oils: Sources, applications, and health effects. Di dalam: Barrow C, Shahidi F (ed). Marine Nutraceuticals and Functional Foods. CRC Press.

Peng S, Chao C, Shi Z, Wang L. 2013. Amino acid and fatty acid composition of the muscle tissue of yellowfin tuna (Thunus albacares) and Bigeye Tuna (Thunus obesus). Journal of Food and Nutrition Research. 1(4):42-45.

Sunarya Y. 2003. Kimia Dasar 2: Berdasarkan Prinsip-prinsip Kimia Terkini. Bandung (ID): Alkemi Grafisindo Press.

Taheri S, Motalebi AA, Fazlara A. 2012. Antioxidant effect of ascorbic acid on the 
quality of cobia (Rachycentron canadum) fillets during frozen storage. Iranian Journal of Fisheries Sciences. 11(3): 666680.

Telahigue K, Hajii T, Rabeh I, El-Cafsi M. 2013. The changes of fatty acid composition in sun dried, oven dried, and frozen hake (Merluccius merluccius) and sardinella (Sardinella aurita). African Journal of Biochemistry Research. 7(8): 158-164.

Thoha. 2004. Asam lemak esensial untuk optimalisasi fungsi otak balita. [tesis]. Bogor (ID): Program Pascasarjana, Program Studi Gizi Masyarakat, Institut Pertanian Bogor.

Tonial IB, de Oliveira DF, Coelho AR, Matsushita M, Coro FAG, de Souza, NE, Visentainer, JV. 2014. Quantification of essential fatty acids and assessment of the nutritional quality indexes of lipids in tilapia alevins and juvenile tilapia fish (Oreochromis niloticus). Journal of Food
Research. 3(3): 105-114.

Winarno FG. 1997. Kimia Pangan dan Gizi. Jakarta (ID): PT Gramedia Utama

Wozniack M, Podzycinski P, Kozlowski K. 2013. The nutritional value of selected species of fish from lake and fish farm of north-eastern Poland. Polish Journal of Natural Science. 28(2): 295-304.

Wu X, Zhou B, Cheng Y, Zeng C, Wang C, Feng L. 2010. Comparison of gender diff erences in biochemical composition and nutritional value of various edible parts of the blue swimmer crab. Journal of Food Composition and Analysis. 23:154-159.

Zuraini A, Somchit MN, Solihah MH, Goh YM, Arifah AK, Zakaria MS, Somchit N, Rajio MA, Zakaria ZA, Mat JAM. 2006. Fatty acid and amino acid composition of three local malaysian Channa spp. fish. Food Chemistry. 97: 674-678. 